\title{
Ulasan Peraturan
}

\section{Peraturan Presiden Nomor 22 Tahun 2017 tentang Rencana Umum Energi Nasional}

\author{
Grita Anindarini Widyaningsih ${ }^{1}$
}

\section{Pendahuluan}

Pada 13 Maret 2017, Peraturan Presiden Nomor 22 Tahun 2017 Tentang Rencana Umum Energi Nasional (selanjutnya disebut "Perpres RUEN") diundangkan.2 Diundangkannya Perpres RUEN ini merupakan amanat dari Peraturan Pemerintah Nomor 79 Tahun 2014 Tentang Kebijakan Energi Nasional. ${ }^{3}$ Secara keseluruhan, baik RUEN maupun Kebijakan Energi Nasional ini merupakan amanat dari UU No. 30 Tahun 2007 Tentang Energi, yang pembentukannya bertujuan untuk dapat memenuhi kebutuhan energi dalam negeri secara berkelanjutan, berkeadilan dan optimal dalam rangka mencapai ketahanan energi nasional. Nantinya, rencana yang ada di Perpres RUEN tersebut akan dijadikan acuan dalam penyusunan Rencana Umum Energi Daerah (RUED) untuk dapat memenuhi kebutuhan energi di daerah masing-masing secara berkelanjutan, berkeadilan dan optimal dalam rangka mencapai ketahanan energi di daerah dan sesuai dengan tujuan pengelolaan energi secara nasional. ${ }^{4}$

Secara garis besar, Perpres RUEN ini disusun oleh Pemerintah dan ditetapkan oleh Dewan Energi Nasional untuk jangka waktu sampai dengan tahun 2050 yang

1 Penulis adalah Asisten Peneliti di Indonesian Center for Environmental Law.

2 Presiden RI (a), Peraturan Presiden tentang Rencana Umum Energi Nasional, Perpres No. 22 Tahun 2017, LN No. 43 Tahun 2017.

3 Indonesia (a), Peraturan Pemerintah tentang Kebijakan Energi Nasional, PP No. 79 Tahun 2014, LN No. 300 Tahun 2014, TLN No. 5609.

4 Badan Perencanaan Pembangunan Nasional. Policy Paper Keselarasan Kebijakan Energi Nasional Dengan Rencana Umum Energi Nasional dan Rencana Umum Energi Daerah. Jakarta : 2012, hlm. 23. 
memuat: a) Pendahuluan, kondisi energi nasional saat ini dan ekspektasi masa mendatang ; b) Visi, misi, tujuan dan sasaran energi nasional ; c) Kebijakan dan strategi pengelolaan energi nasional; serta d) Penutup. Adapun Perpres RUEN ini memiliki fungsi sebagai landasan untuk penyusunan rencana-rencana yang lebih teknis ke depannya, seperti Rencana Umum Penyediaan Tenaga Listrik oleh PLN, rencana penyusunan APBN/APBD oleh Kementerian, Lembaga dan Pemerintah Daerah terkait, pedoman Kementerian dan Lembaga untuk menyusun rencana strategis, hingga pedoman Pemerintah Provinsi untuk menyusun Rencana Umum Energi Daerah Provinsi (RUED-P). ${ }^{5}$ Mengingat luasnya pembahasan dalam Perpres RUEN, maka khusus untuk ulasan peraturan perundang-undangan ini, Penulis akan membatasi pembahasan kepada kebijakan dan strategi pengelolaan energi nasional serta isu-isu terkait perlindungan dan pengelolaan lingkungan hidup yang tercantum dalam Perpres RUEN.

\section{Kebijakan dan Strategi Pengelolaan Energi Nasional Pasca Perpres}

\section{No. 22 Tahun 2017}

Pada peraturan induknya, PP No. 79 Tahun 2014 terkait Kebijakan Energi Nasional, dua arah kebijakan pengelolaan energi nasional telah ditetapkan, yakni kebijakan utama dan kebijakan pendukung. Lebih jauh, dalam peraturan tersebut pengelolaan energi nasional diutamakan untuk memenuhi kebutuhan energi nasional. ${ }^{6}$ Adanya prioritas ini ditujukan untuk mencapai tujuan utama Kebijakan EnergiNasional2050yaitu KemandiriandanKetahanan EnergiNasional.Disamping kebijakan utama tersebut, pengelolaan energi nasional juga ditujukan untuk berbagai kebijakan pendukung. Beberapa diantaranya adalah untuk lingkungan hidup dan keselamatan, penelitian serta pengembangan dan penerapan teknologi energi, hingga kelembagaan dan pendanaan. ${ }^{7}$ Untuk dapat mencapai tujuan

5 Humas Sekretariat Kabinet, "RUEN, Rencana Umum Energi Nasional", http:// setkab.go.id/ ruen-rencana-umum-energi-nasional/, diunduh pada 21 Agustus 2017.

6 Indonesia (a), op.cit., ps. 3 ayat (2). Lebih lanjut dalam pasal tersebut dijelaskan bahwa kebijakan utama untuk kebijakan energi nasional meliputi: a) Ketersediaan energi untuk kebutuhan nasional ; b) Prioritas pengembangan energi ; c) Pemanfaatan sumber daya energi nasional ; dan d) Cadangan energi nasional.

$7 \quad$ Ibid., ps. 3 ayat (3). 
tersebut, Perpres RUEN mendetailkan bahwa prioritas pengembangan energi Indonesia kedepannya harus didasarkan pada prinsip berikut: 1) Memaksimalkan penggunaan energi terbarukan dengan memperhatikan tingkat keekonomian ; 2) Meminimalkan penggunaan minyak bumi ; 3) Mengoptimalkan pemanfaatan gas bumi dan energi baru ; serta 4) Menggunakan batubara sebagai andalan pasokan energi nasional. Berikut adalah penjabaran lebih lanjut terkait prioritas pengembangan energi ini. ${ }^{8}$

\section{II.1. Memaksimalkan Penggunaan Energi Terbarukan}

Pada dasarnya, inisiatif untuk mengembangkan Energi Baru dan Terbarukan ("EBT") telah ada sejak dulu namun memang pemanfaatan dan pengembangannya yang belum maksimal. Setidaknya hingga saat ini, pemanfaatan EBT baru mencapai sekitar $2 \%$ dari total potensi EBT yang ada. ${ }^{9}$ Adapun sebab rendahnya pemanfaatan dan pengembangan EBT ini terjadi antara lain karena: a) Belum maksimalnya pelaksanaan kebijakan harga ; b) Ketidakjelasan subsidi EBT pada sisi pembeli (off-taker) ; c) Regulasi yang belum dapat menarik investasi; d) Belum adanya insentif bagi pengembangan EBT; e) Minimnya ketersediaan instrumen pembiayaan yang sesuai dengan kebutuhan investasi; f) Proses perizinan yag rumit; hingga g) permasalahan lahan dan tata ruang. ${ }^{10}$ Menghadapi hal ini, RUEN-pun mengamanatkan untuk mengoptimalkan pengembangan EBT ke depannya. Bahwa setidaknya rencana pengembangan EBT ke depannya adalah paling sedikit $23 \%$ dari total bauran energi primer pada tahun 2025 dan paling sedikit 31\% dari total bauran energi primer pada tahun $2050 .^{11}$

Terdapat berbagai sumber EBT yang telah diatur dalam Perpres RUEN yang untuk kedepannya diharapkan dapat dikembangkan di Indonesia, diantaranya adalah panas bumi, tenaga air, minihidro dan mikrohidro, bioenergi, tenaga suya, bayu atau angin, serta arus, gelombang, dan perbedaan suhu lapisan laut. Pada dasarnya, pengembangan EBT ini tidak hanya diproyeksikan untuk pembangkit, namun juga EBT ini diharapkan dapat dikembangkan sebagai

8 Presiden RI (a), op.cit., Lampiran I., hlm. 36-38.

9 Ibid., Lampiran I, hlm. 20

10 Ibid.,Lampiran I, hlm. 13

11 Ibid., Lampiran I, hlm. 20 
energi yang digunakan secara langsung oleh sektor pengguna. Khusus untuk rencana pembangunan pembangkit tenaga EBT, berikut adalah tabel rencana pemodelan pembangunan pembangkit tenaga EBT di Indonesia:

\begin{tabular}{|l|l|l|l|}
\hline \multicolumn{1}{|c|}{ Jenis Energi } & \multicolumn{1}{|c|}{$\begin{array}{c}\text { Terpasang } \\
\text { (per 2016) }\end{array}$} & \multicolumn{1}{|c|}{$\begin{array}{c}\text { Target } \\
\text { Tahun 2025 }\end{array}$} & \multicolumn{1}{|c|}{$\begin{array}{c}\text { Target } \\
\text { Tahun 2050 }\end{array}$} \\
\hline Panas Bumi & $1.653,5$ & $7.241,5$ & $17.546,0$ \\
\hline Air & $4.871,7$ & $17.986,7$ & $38.000,0$ \\
\hline $\begin{array}{l}\text { Minihidro dan } \\
\text { mikrohidro }\end{array}$ & 230,5 & $3.000,0$ & $7.000,0$ \\
\hline Bioenergi & $1.801,6$ & $5.500,0$ & $26.000,0$ \\
\hline Surya & 107,8 & $6.500,0$ & $45.000,0$ \\
\hline Angin & 3,9 & $1.800,0$ & $28.000,0$ \\
\hline $\begin{array}{l}\text { Energi Terbarukan } \\
\text { lainnya }\end{array}$ & 809,8 & $3.125,0$ & $6.100,0$ \\
\hline
\end{tabular}

Tabel 1 : Pemodelan Pengembangan Energi Terbarukan di Indonesia (satuan: MW) ${ }^{2}$

Sekilas memang terlihat target untuk pemodelan pengembangan pembangkit EBT tersebut terkesan ambisius. Namun, untuk mencapai target tersebut, secara umum di dalam Perpres RUEN tersebut telah ditetapkan beberapa langkah untuk mengejar pembangunan pembangkit EBT ini, yakni: ${ }^{12}$

1) Membentuk badan usaha EBT tersendiri yang ditugasi Pemerintah untuk mengembangkan, memanfaatkan, dan/atau membeli EBT;

2) Menerapkan dan menyempurnakan feed in tariff dari pembangkit EBT keada badan usaha ketenagalistrikan yang berlaku selama harga listrik EBT lebih tinggi dari harga listrik dari sumber energi primer lainnya;

3) Menyusun pedoman pemberian subsidi energi oleh Pemerintah Daerah yang anggarannya dialokasikan dalam APBD;

4) Menganggarkan pembangunan infrastruktur EBT secara berkelanjutan untuk desa-desa yang tidak akan terlistriki dalam jangka panjang;

5) Menugaskan lembaga pembiayaan infrastruktur nasional untuk membiayai proyek pembangunan EBT; serta

1 Ibid., lampiran I hlm. 63, bahwa yang dimaksud dengan energi terbarukan lainnya adalah PLTD dengan campuran bioenergy, PLT Arus Laut, PLT Gelombang Laut, serta PLT Energi Panas Laut (Ocean Thermal Energy).

2 Disarikan dan dirangkum oleh Penulis dari Lampiran I, hlm. 63-64

12 Ibid., lampiran I hlm. 66. 
6) Mengembangkan sistem tenaga listrik kecil berbasis EBT untuk penyediaan listrik di wilayah-wilayah yang tidak terjangkau oleh perluasan jaringan (grid).

\section{II.2. Meminimalkan Penggunaan Minyak Bumi}

Menyadari bahwa cadangan sumber daya minyak bumi nasional yang semakin menipis, Perpres RUEN menetapkan kebijakan untuk pengurangan penggunaan minyak bumi serta mengurangi ketergantungan terhadap impor. ${ }^{13}$ Adapun kedepannya diharapkan penggunaan minyak bumi dalam bauran energi primer adalah sebesar 24,7\% pada tahun 2025 dan semakin menurun menjadi 19,5\% pada tahun 2050. Selain itu, berkaitan dengan impor, diharapkan pada tahun 2025 sudah tidak ada lagi impor BBM. Hal ini merupakan sebuah pekerjaan rumah yang cukup berat mengingat saat ini porsi impor BBM nasional masih sekitar $52 \%{ }^{14}$ dan butuh program yang ekstra untuk mewujudkan pengurangan tersebut. Secara khusus, Perpres RUEN juga menawarkan upaya untuk pengurangan ketergantungan impor ini, yakni dengan peningkatan kapasitas kilang melalui pembangunan kilang baru dan revitalisasi kilang minyak yang telah ada serta diversifikasi ke bahan bakar lain. ${ }^{15}$

Secara garis besar kecenderungan produksi minyak bumi domestik diperkirakan menurun karena tambahan produksi dari lapangan baru belum dapat mengimbangi penurunan produksi dari lapangan lama. Adapun tingkat penurunan ini rata-rata sekitar $6 \%$ per tahun. Adanya penurunan ini tentu dikhawatirkan akan menjadi penghambat dalam pemenuhan kebutuhan minyak dalam negeri. Untuk itu, Perpres RUEN memperkirakan tambahan produksi akan diperoleh dari penemuan cadangan baru dan kegiatan enhanced oil recovery (EOR). ${ }^{16} \mathrm{Hal}$ ini semata-mata juga dilakukan untuk dapat

13 Ibid., lampiran I hlm. 36.

14 Ibid., lampiran I hlm. 40.

15 Ibid., Lampiran I hlm. 40

16 Ibid., Lampiran I hlm. 42. Adapun perkiraan ini dilakukan dengan asumsi : a) pada tahun 2016 rasio pemulihan cadangan mencapai $60 \%$ dan terus meningkat hingga mencapai $100 \%$ pada tahun 2025; b) Dalam jangka waktu 5 tahun, 6,4\% dari setiap penemuan cadangan baru dapat diproduksikan dengan tetap mempertimbangkan tingkat penurunan sebesar $10 \%$; dan c) Kegiatan EOR mulai produksi tahun 2020 dengan jumlah cadangan yang bisa dipulihkan sampai tahun 2050 sebesar 2,5 miliar barel dengan asumsi penurunan produksi sebesar 10\%. Lebih lanjut yang dimaksud dengan Enhanced Oil Recovery (EOR) adalah penggunaan teknik yang berbeda yang dapat dipergunakan untuk meningkatkan produksi minyak men- 
memastikan produksi minyak bumi tidak kurang dari 567,7 ribu BOPD pada tahun 2025.

\section{II.3. Mengoptimalkan Pemanfaatan Gas Bumi dan Energi Baru}

Dalam RUEN ini juga dijelaskan terkait dengan fokus Pemerintah untuk mengoptimalkan pemanfaatan gas bumi demi kebutuhan dalam negeri. Nantinya, gas bumi ini diharapkan dapat dipergunakan untuk bahan bakar pembangkit tenaga listrik, transportasi, rumah tangga, dan bahan baku industri. Selain itu, pemanfaatan energi baru juga diprioritaskan. Adapun yang dimaksud dengan energi baru di sini adalah gasifikasi batubara, batubara tercairkan, gas metana batubara, serta hidrogen. ${ }^{17}$ Pemerintah melihat bahwa energi baru ini memiliki potensi yang cukup besar namun sayangnya hingga saat ini masih belum dikembangkan.

Terkait dengan pemanfaatan gas bumi untuk kebutuhan dalam negeri ini, Negara tetap bergantung kepada produksi gas bumi dalam negeri dan impor LPG sebagai pemenuhannya. Untuk produksi gas bumi dalam negeri, nantinya akan dimanfaatkan untuk menghasilkan energi final berupa listrik, LPG, dan dimethyl Ether (campuran LPG). Di samping itu, untuk hasil impor LPG nantinya akan langsung dimanfaatkan untuk sektor industri, transportasi, rumah tangga, komersial, dan sektor lainnya oleh para end-user. ${ }^{18}$ Adanya impor gas alam ini dibutuhkan karena Pemerintah memperkirakan bahwa pada tahun 2020, Indonesia berpotensi mengalami defisit gas dan akan terus meningkat hingga tahun $2050 .{ }^{19}$ Secara garis besar, pada tahun 2020 kebutuhan gas bumi dalam negeri akan mencapai 6.037,8 MMSCFD, sementara kemampuan berproduksi diperkirakan hanya 5.732,0 MMSCFD. Adapun kejadian defisit ini diperkirakan akan terus meningkat hingga 2050.

tah dari sumur. Pada dasarnya, metode yang dipergunakan adalah dengan thermal, bahan kimia, serta penggunaan gas. Dikutip dari: “Enhanced Oil Recovery (EOR)”, https://www. petropedia.com/definition/202/enhanced-oil-recovery-eor, diunduh pada 23 Agustus 2017.

18 Ibid., Lampiran I hlm. 48.

19 Ibid., Lampiran I hlm. 51. Adapun dalam keterangannya diperkirakan bahwa pada tahun 2020 Indonesia akan mengalami defisit pasokan gas bumi sebesar 401,8 MMSCFD dan akan meningkat hingga 20.201,0 MMSCFD pada tahun 2050. Adapun angka ini diperhitungkan dengan membandingkan kebutuhan gas bumi dalam negeri dan committed production pada tahun berjalan. Angka ini tidak termasuk kebutuhan impor LPG. 
Selain itu, demand terkait LPG-pun terus meningkat. Pada 2017 diperkirakan permintaan mencapai 7,3 juta ton dan akan terus meningkat hingga 13,2 juta ton pada $2050 .^{20}$

Untuk mencapai sasaran pengembangan energi gas bumi tersebut, beberapa kegiatan yang dicanangkan akan dilakukan diantaranya:21 a) Memastikan produksi gas bumi menjadi tidak kurang dari 6.700 juta MMSCFD pada tahun 2025 ; b) Menyelesaikan kebijakan harga gas bumi dengan membentuk badan penyangga gas nasional ; c) Meningkatkan rasio pemulihan cadangan gas bumi hingga mencapai 100\% pada tahun 2025, dengan meningkatkan kegiatan eksplorasi secara masif menjadi tiga kali lipat ; d) Mempercepat penyelesaian proyek gas bumi ; e) Mempercepat penyelesaian pembangunan infrastruktur gas bumi ; f) Mengendalikan impor LPG menjadi di bawah 50\% dari kebutuhan gas nasional pada tahun 2050 ; hingga g) menetapkan harga gas yang kompetitif untuk konsumen dalam negeri untuk meningkatkan nilai tambah.

Terkait dengan pengembangan energi baru, hal ini belum terlalu banyak dibahas secara detail di dalam RUEN ini. Namun, beberapa hal yang telah dibahas pemanfaatannya adalah Pemerintah memiliki strategi untuk melakukan komersialisasi menara bor purwarupa (prototype rig) untuk coal bed methane (CBM) yang telah dibuat dengan target 2 unit per tahun, dalam rangka meningkatkan dan mengefisienkan kegiatan eksplorasi dan eksploitasi CBM.22 Selain itu, untuk pengembangan coal liquefaction (batubara tercairkan), nampaknya hingga saat ini masih dalam tahap pengembangan awal. Dalam RUEN dijelaskan bahwa Pemerintah masih mengarahkan untuk adanya penyusunan peta jalan dan kebijakan pengembangan sumber energi batubara berbentuk cair tersebut. Di samping itu, perlu adanya pengembangan teknologi produksi dan penggunaan bahan bakar sintetis dan hidrogen untuk transportasi serta arahan untuk mempercepat pengembangan batubara tercairkan sebagai bahan bakar cair. ${ }^{23}$

$20 \quad$ Ibid., Lampiran I hlm. 52.

21 Ibid., Lampiran I hlm. 54 - 56.

22 Ibid., Lampiran II, hlm. 10.

23 Ibid., Lampiran II, hlm. 45. 


\section{II.4. Menggunakan batubara sebagai andalan pasokan energi nasional}

Pemerintah menyadari bahwa Indonesia memiliki potensi sumber daya batubara yang cukup besar. Untuk itu, Pemerintah tetap memprioritaskan sumber energi primer ini sebagai pasokan energi nasional. Namun, dalam Perpres RUEN sendiri, batubara diupayakan untuk dapat digunakan sebagai pilihan "terakhir" untuk pemenuhan kekurangan kebutuhan dalam negeri setelah memaksimalkan penggunaan energi terbarukan, meminimalkan penggunaan minyak bumi, dan mengoptimalkan pemanfaatan gas bumi dan energi baru. ${ }^{24}$ Pemerintah juga mengupayakan untuk mengolah batubara tersebut dengan menggunakan teknologi bersih yang ramah lingkungan.

Secara garis besar, Pemerintah Indonesia mencanangkan untuk mengurangi ketergantungan terhadap batubara hingga hanya 30,0\% (119,8 MTOE) pada tahun 2025 dan 25,3\% (255,9 MTOE) pada tahun 2050. Selain itu, Pemerintah juga mencanangkan untuk mengendalikan produksi batubara mulai tahun 2019 hingga sebesar 400 juta ton - kecuali kebutuhan domestik melebihi 400 juta ton. Selain itu, ekspor batubara juga akan dihentikan paling lambat pada tahun 2046. ${ }^{25}$ Dalam kaitannya untuk mengendalikan produksi batubara tersebut, Pemerintah akan melakukan moratorium pemberian Izin Usaha Pertambangan dan Izin Usaha Petambangan Khusus batubara di hutan alam primer dan lahan gambut yang berada di hutan konservasi, hutan lindung, hutan produksi, dan area penggunaan lain. ${ }^{26}$ Namun sayangnya, belum dijelaskan bagaimana tahap moratorium ini dilakukan.

Adapun Pemerintah juga menyadari bahwa batubara hingga saat ini masih menjadi tumpuan untuk sektor kelistrikan. Mengingat pembangunan PLTU Batubara hingga saat ini menjadi salah satu sumber emisi terbesar di Indonesia ${ }^{27}$, hal ini tentu menjadi pertanyaan tersendiri mengingat komitmen Indonesia untuk dapat mengambil cara-cara strategis dalam mengurangi emisi gas rumah kaca. Menanggapi hal itu, Pemerintah akan mewajibkan pemanfaatan teknologi energi batubara yang ramah lingkungan (Clean Coal

$24 \quad$ Ibid., Lampiran I hlm. 37

25 Ibid., Lampiran I, hlm. 59.

26 Ibid., Lampiran I, hlm. 60.

27 Kementerian Energi dan Sumber Daya Mineral, Data Inventory Emisi GRK Sektor Energi, (Kementerian ESDM, Jakarta: 2016), hlm. v. 
Technology) dan efisiensi tinggi (Ultra Super Critical) secara bertahap. ${ }^{28}$ Namun sayangnya kembali, tidak dijelaskan bagaimana tahap untuk penerapan teknologi CCT dan USC tersebut.

\section{Isu Terkait Perlindungan dan Pengelolaan Lingkungan Hidup Dalam RUEN}

Dalam perjalanannya, pengelolaan energi tidak pernah terlepas dari isu perlindungan dan pengelolaan lingkungan hidup. Hal ini juga telah dijabarkan secara cukup detail dalam RUEN ini. Pada dasarnya, indikator lingkungan hidup merupakan salah satu dasar dalam penyusunan proyeksi permodelan kebutuhan dan pasokan energi jangka panjang. Adapun dalam indikator lingkungan hidup tersebut, indikator yang digunakan adalah jumlah emisi gas rumah kaca, emisi gas rumah kaca per kapita, dan emisi gas rumah kaca per PDB ${ }^{29}$. Berdasarkan data yang dihimpun, emisi GRK di Indonesia dari sektor energi meningkat dari 433,5 juta ton $\mathrm{CO}_{2}$ pada 2013 menjadi 464,4 juta ton $\mathrm{CO}_{2}$ pada 2014 ${ }^{30}$. Sebagian besar sumber emisi GRK tersebut berasal dari pembangkit listrik (33\%), diikuti oleh industri (30\%), transportasi (29\%), dan sektor lainnya (8\%). ${ }^{31}$ Besarnya emisi ini disebabkan karena penggunaan energi fosil batubara di sektor pembangkit dan industri, serta BBM pada sektor transportasi. Adanya pertumbuhan emisi $\mathrm{CO}_{2}$ ini relatif meningkat seiring dengan peningkatan pertumbuhan PDB. Hal ini berarti sebagian besar emisi $\mathrm{CO}_{2}$ berkaitan langsung dengan pertumbuhan ekonomi yang tidak disertai dengan efisiensi emisi $\mathrm{CO}_{2}$.

Melihat permasalahan dalam indikator tersebut, Perpres RUEN telah menetapkan bahwa isu lingkungan hidup termasuk dalam kebijakan pendukung dalam pengelolaan energi nasional. Berbagai program dan kegiatan-pun dilancarkan untuk mendukung pengelolaan tersebut. Adapun program dan kegiatan ini dilakukan lintas-lembaga dengan menunjuk satu kementerian terkait sebagai koordinator pelaksananya. Berikut adalah beberapa strategi/program tersebut:

\footnotetext{
$28 \quad$ Ibid.

29 Ibid., Lampiran I, hlm. 21.

$30 \quad$ Ibid.

31 Ibid., Lampiran I, hlm. 22.
} 


\section{III.1. Pengendalian emisi gas rumah kaca dari sektor energi}

Berkiatan dengan program ini, terdapat dua Kementerian yang menjadi koordinator yakni Kementerian Energi dan Sumber Daya Mineral ("Kementerian ESDM") serta Kementerian Lingkungan Hidup dan Kehutanan ("KLHK"). Adapun seperti yang telah dijelaskan sebelumnya, Kementerian ESDM ditugaskan untuk dapat melaksanakan konservasi energi di sisi suplai energi serta mewajibkan pemanfaatan teknologi energi batubara yang ramah lingkungan (Clean Coal Technology) dan efisiensi tinggi (Ultra Super Critical) secara bertahap. Selain itu, KLHK difokuskan untuk dapat melaksanakan Perpres Nomor 61 Tahun 2011 tentang Rencana Aksi Nasional - Gas Rumah Kaca (“RAN GRK”) 32 secara konsisten untuk mendukung program ini. Secara koordinatif, Kementerian ESDM dan KLHK juga memiliki tugas untuk dapat memperhatikan reklamasi lahan pasca tambang batubara serta melaksanakan program audit dan manajemen energi. ${ }^{33}$ Keseluruhan kegiatan ini nantinya akan dituangkan dalam Rencana Strategis Kementerian/Lembaga, kecuali untuk kegiatan melaksanakan konservasi energi di sisi suplai energi, yang nantinya akan diatur tersendiri dalam Permen ESDM terkait dengan konservasi energi.

Sedikit menelisik ke belakang, Indonesia sendiri memang berkomitmen untuk mengendalikan emisi gas rumah kaca, termasuk dari sektor energi. Komitmen ini tertuang dalam Paris Agreement, yang mana telah diratifikasi oleh Indonesia melalui UU No. 16 Tahun 2016 Tentang Pengesahan Paris Agreement to The United Nations Framework Convention on Climate Change (Persetujuan Paris atas Konvensi Kerangka Kerja Perserikatan Bangsa-Bangsa Mengenai Perubahan Iklim). Di dalam persetujuan tersebut, Indonesia bersama negara-negara di dunia berkomitmen untuk mengurangi kenaikan suhu di dunia hingga 2 derajat celcius pada tahun 2020 mendatang. Lebih lanjut, Indonesia juga tengah merancang Nationally Determined Contribution yang

32 Presiden RI (b), Peraturan Presiden tentang Rencana Aksi Nasional Penurunan Emisi Gas Rumah Kaca, Perpres No. 61 Tahun 2011, ps. 1 ayat (1), yang untuk selanjutnya dijelaskan bahwa RAN-GRK adalah Rencana Aksi Nasional Penurunan Emisi Gas Rumah Kaca dan merupakan sebuah dokumen rencana kerja untuk pelaksanaan berbagai kegiatan yang secara langsung dan tidak langsung menurunkan emisi gas rumah kaca sesuai dengan target pembangunan nasional

33 Presiden RI (a), op.cit., Lampiran II, Hlm. 70. 
menggambarkan bagaimana peningkatan aksi dan kondisi yang mendukung selama periode 2015-2019 yang akan berkontribusi dalam upaya untuk mencegah kenaikan temperatur global tersebut. ${ }^{34}$ Dari sektor energi sendiri, diharapkan dapat berkontribusi untuk mengurangi emisi di Indonesia sebesar 11\% dari total NDC apabila dibandingkan dengan sektor lainnya, seperti limbah, Instalasi Pengontrol Polusi Udara (“IPPU”), pertanian, dan kehutanan.

Untuk mewujudkan hal tersebut, Rida Mulyana, Direktur Jenderal Energi Baru, Terbarukan dan Konservasi Energi - Kementerian Energi dan Sumber Daya Mineral menyampaikan bahwa di sektor energi sendiri, Indonesia berkomitmen untuk menurunkan emisi gas rumah kaca sesuai NDC pada tahun 2030.35 Pihak Kementerian ESDM juga telah menyiapkan rencana aksi untuk memenuhi hal ini. Beberapa diantaranya adalah menggencarkan pembangunan pembangkit listrik tenaga energi terbarukan, menggalakkan reklamasi pasca tambang, penggunaan biodiesel untuk transportasi, penerapan managemen energi di industri dan bagunan komersial, hingga penerapan standard/label pada peralatan rumah tangga dan industri. Selain itu, menyikapi masih diandalkannya PLTU Batubara untuk elektrifikasi di Indonesia, Rida menegaskan bahwa pihaknya akan mewajibkan bagi pemanfaatan teknologi CCT dan USC untuk PLTU yang baru. ${ }^{36}$

\section{III.2. Penyediaan energi dan pemanfaatan energi yang berwawasan lingkungan}

Dalam strategi ini, Kementerian Lingkungan Hidup dan Kehutanan serta Kementerian Perindustrian akan menjadi koordinator dalam pelaksanaannya. Adapun strategi ini untuk selanjutnya dibagi menjadi tiga program, yakni: ${ }^{37}$

1) Pencegahan, penanggulangan, dan pemulihan dampak lingkungan hidup;

2) Pengurangan dan penggunaan kembali produksi limbah, serta mengekstrak unsur yang masih bisa dimanfaatkan ; serta

34 Kementerian Lingkungan Hidup dan Kehutanan, First Nationally Determined Contribution Republic of Indonesia, Jakarta, hlm. 2.

35 Disampaikan oleh Rida Mulyana, Direktur Jenderal Energi Baru, Terbarukan dan Konservasi Energi - Kementerian Energi dan Sumber Daya Mineral, dalam acara Parallel Session Seminar "Indonesia NDC: Progress dan Tindak Lanjut" Pada Jum'at, 4 Agustus 2017 di Kementerian Lingkungan Hidup dan Kehutanan.

36 Ibid.

37 Presiden RI (a), op.cit., Lampiran 2, hlm. 72. 
3) Peningkatan koordinasi dan layanan perizinan dalam kawasan hutan.

Terkait dengan strategi pencegahan, penanggulangan dan pemulihan dampak lingkungan hidup, Kementerian Lingkungan Hidup dan Kehutanan bertanggung jawab untuk mengintegrasikan kebijakan lingkungan mencakup perencanaan, pemanfaatan, pengendalian, pemulihan, pengawasan, dan penegakan hukum. Sayangnya, dalam kegiatan ini tidak dijelaskan secara lebih konkrit bagaimana tindak lanjutnya.

Terkait dengan strategi pengurangan dan penggunaan kembali produksi limbah, serta mengekstrak unsur yang masih bisa dimanfaatkan, beberapa kegiatan yang akan dilakukan adalah mendorong peningkatan penggunaan teknologi energi yang ramah lingkungan berdasarkan prinsip 3R (reuse, reduce, and recycle), memanfaatkan limbah produk energi secara berkelanjutan, serta memanfaatkan gas buang untuk listrik dan proses termal di industri. ${ }^{38}$

Terkait dengan peningkatan koordinasi dan layanan perizinan dalam kawasan hutan adalah memfasilitasi proses layanan penerbitan izin pemanfaatan kawasan hutan untuk pengusahaan tenaga air, panas bumi, migas dan batubara termasuk sarana dan prasarana, dan instalasi pembangkit, transmisi dan distribusi listrik serta teknologi energi baru dan terbarukan - serta moratorium pemberian izin usaha pertambangan dan izin usaha pertambangan khusus batubara di hutan alam primer dan lahan gambut yang berada di hutan konservasi, hutan lindung, hutan produksi, dan area penggunaan lain. ${ }^{39}$

\section{Rekomendasi}

Pada dasarnya, Perpres RUEN telah memberikan penjelasan yang detail dalam hal rencana pengelolaan energi di tingkat nasional. Namun, hal yang perlu untuk diperhatikan lebih lanjut adalah bagaimana Perpres RUEN ini kemudian dapat diimplementasikan dan disinergiskan dengan peraturan pelaksananya. Sebagai contoh, ketika Perpres RUEN telah memandatkan untuk membatasi penggunaan

$38 \quad$ Ibid.

39 Ibid., hlm. 73. 
tenaga batubara hingga 30\% pada tahun 2025, namun justru di RUPTL PLN 20172026 ditetapkan bahwa PLTU batubara akan mendominasi jenis pembangkit yang akan dibangun, yaitu mencapai $41 \%{ }^{40}$ Pada contoh lain, Perpres RUEN juga mengamanatkan bahwa paling sedikit pembangunan pembangkit listrik tenaga EBT adalah 23\% dari total pembangkit di Indonesia pada tahun 2025. Namun, ketika merujuk kepada RUPTL PLN 2017-2026, pembangunan pembangkit tenaga EBT diperkirakan paling besar 22\%. Bahkan, RUPTL PLN juga telah memberikan rencana cadangan apabila target $22 \%$ tersebut tidak terpenuhi, yakni dengan pengembangan pembangkit listrik dengan gas.

Perlu untuk diperhatikan bahwa seharusnya adanya Perpres RUEN ini dijadikan sebagai dasar untuk pembentukan peraturan teknis yang lebih "ambisius" atau setidak-tidaknya dapat sama targetnya dengan yang telah dicanangkan dalam Perpres RUEN tersebut. Sangat disayangkan apabila Perpres RUEN ini kemudian tidak ditindaklanjuti dengan peraturan teknis yang sejalan. Untuk itu rasanya diperlukan peninjauan ulang terhadap RUPTL PLN 2017-2026 agar dapat menyesuaikan dengan Perpres RUEN yang berlaku. Disamping dengan RUPTL PLN, peran serta masyarakat juga sangat dibutuhkan untuk mengawal pembentukan RUED-Provinsi yang merupakan pengejawantahan dari Perpres RUEN tersebut. Harapannya, dengan adanya pengawalan ini dapat menjaga agar amanat-amanat yang telah tercantum dalam Perpres RUEN dapat ditindaklanjuti dengan sejalan dalam RUED di daerah terkait.

$40 \quad$ Menteri Energi dan Sumber Daya Mineral, Keputusan Menteri Energi dan Sumber Daya Mineral tentang Pengesahan Rencana Usaha Penyediaan Tenaga Listrik PT. Perusahaan Listrik Negara (Persero) Tahun 2017 s/d 2026, Kepmen ESDM No. 1415 K/20/MEM/2017, hlm. VI-3. 


\section{DAFTAR PUSTAKA}

Badan Perencanaan Pembangunan Nasional. Policy Paper Keselarasan Kebijakan Energi Nasional Dengan Rencana Umum Energi Nasional dan Rencana Umum Energi Daerah. Jakarta : Bappenas, 2012.

Humas Sekretariat Kabinet, "RUEN, Rencana Umum Energi Nasional", http://setkab.go.id/ruen-rencana-umum-energi-nasional/, diunduh pada 21 Agustus 2017.

Indonesia, Peraturan Pemerintah tentang Kebijakan Energi Nasional, PP No. 79 Tahun 2014, LN No. 300 Tahun 2014, TLN No. 5609.

Kementerian Energi dan Sumber Daya Mineral, Data Inventory Emisi GRK Sektor Energi, Jakarta: Kementerian ESDM, 2016

Kementerian Lingkungan Hidup dan Kehutanan, First Nationally Determined Contribution Republic of Indonesia. Jakarta: KLHK, 2016.

Menteri Energi dan Sumber Daya Mineral. Keputusan Menteri Energi dan Sumber Daya Mineral tentang Pengesahan Rencana Usaha Penyediaan Tenaga Listrik PT. Perusahaan Listrik Negara (Persero) Tahun 2017 s/d 2026. Kepmen ESDM No. $1415 \mathrm{~K} / 20 / \mathrm{MEM} / 2017$.

Presiden RI, Peraturan Presiden tentang Rencana Umum Energi Nasional, Perpres No. 22 Tahun 2017. LN No. 43 Tahun 2017.

- Peraturan Presiden tnetnag Rencana Aksi Nasional Penurunan Emisi Gas Rumah Kaca, Perpres No. 61 Tahun 2011. 